\title{
Distribution and changes in amounts of the androgen receptor in the pig uterus during the estrous cycle, early pregnancy and after treatment with sex steroids
}

\author{
H Cárdenas and W F Pope \\ Department of Animal Sciences, The Ohio State University, 2027 Coffey Road, Columbus, Ohio 43210, USA \\ (Requests for offprints should be addressed to H Cárdenas; Email: Cardenas-seijas.2@osu.edu)
}

\begin{abstract}
Two experiments were performed to examine the expression of the androgen receptor (AR) gene in the pig uterus. In experiment 1 , immunohistochemistry (IHC) was used to determine the distribution of the AR in uterine tissue of pigs when collected at the first day of estrus (day 0 ) and the mid-luteal phase (day 12) of the estrous cycle, or early pregnancy (day 12, $n=4$ gilts per group). In experiment 2 , $\mathrm{AR}$ immunostaining and AR mRNA in uterine tissue were compared among ovariectomized gilts $(n=4$ per group) following treatment for 4 days with daily injections of: (1) progesterone $(2 \mathrm{mg} / \mathrm{kg}$ bodyweight $(\mathrm{BW}))$, (2) estradiol-17 $\beta\left(\mathrm{E}_{2}, 2 \mu \mathrm{g} / \mathrm{kg} \mathrm{BW}\right)$, (3) $\mathrm{E}_{2}$ plus progesterone (same dosages as 1 and 2 combined), (4) $5 \alpha_{-}$ dihydrotestosterone (DHT, $7 \mu \mathrm{g} / \mathrm{kg} \mathrm{BW}$ ), or (5) vehicle (corn oil). Data were analyzed using ANOVA. In experiment 1, nuclear staining for AR in luminal and glandular epithelia was strong and did not differ in intensity between the two locations. Immunostaining of AR in the myometrium was less $(P<0 \cdot 001)$ intense than in the luminal and glandular epithelia. Nuclei of stromal cells contained AR immunostaining that varied in intensity from strong (mainly in subepithelial stroma) to weak or no staining. Stages of the estrous cycle or early pregnancy did not influence AR immunostaining in the endometrial epithelia and myometrium. In experiment 2 , immunostaining of
\end{abstract}

AR in glandular and luminal epithelia and myometrium of ovariectomized gilts treated with vehicle or DHT was less $(P<0.05)$ than in gilts treated with $\mathrm{E}_{2}$, progesterone, or $\mathrm{E}_{2}$ plus progesterone. Immunostaining of AR did not differ between ovariectomized gilts treated with vehicle or $\mathrm{DHT}$, or between gilts treated with $\mathrm{E}_{2}$, progesterone, or $\mathrm{E}_{2}$ plus progesterone. In both experiments, intensity of AR immunostaining was greater in glandular epithelium located at the adluminal region compared with glandular epithelium located at the basal region of the endometrium. Competitive reverse-transcription PCR (RT-PCR) indicated a stimulatory effect $(P<0 \cdot 01)$ of $\mathrm{E}_{2}$ on amounts of AR mRNA in whole endometrium. This increase in AR mRNA after $E_{2}$ treatment was not detected when $E_{2}$ was combined with progesterone. Endometrial AR mRNA was not influenced by DHT or progesterone relative to vehicle-treated gilts. In conclusion, immunoreactive AR is mainly present in luminal and glandular epithelia of the pig uterus and to a lesser extent in the myometrium, and does not change significantly during the estrous cycle or early pregnancy. Expression of the AR gene in the pig endometrium and myometrium appears to be regulated by $\mathrm{E}_{2}$ and progesterone.

Journal of Endocrinology (2003) 177, 461-469

\section{Introduction}

Androgens are considered male sex hormones, however they are also secreted and appear to have regulatory functions in females. Androgens in female mammals originate from the ovaries and adrenal glands. In pigs, androgens have been detected in follicular fluid and corpora lutea (Przala et al. 1984, Grant et al. 1989, Smith et al. 1992), however plasma concentrations of androgens during the porcine estrous cycle have been only partially described. Other sources of androgens such as elongating blastocysts (Fisher et al. 1985) and the placenta (Legrand

et al. 1984) could increase local amounts of androgens and perhaps influence specific physiological processes related to pregnancy.

The function of androgens in females is beginning to be elucidated. It has been demonstrated that treatment with androgens enhanced ovarian follicular development in pigs and primates (Cárdenas \& Pope 1994, Vendola et al. 1998, Cárdenas et al. 2002), and altered epithelial cell proliferation and expression of the thioredoxin gene in the rat uterus (Armstrong et al. 1976, Sahlin et al. 1999, Weihua et al. 2002). The androgen receptor (AR), a transcription factor that belongs to the superfamily of nuclear receptors, 
mediates the actions of the biologically active androgens, testosterone and $5 \alpha$-dihydrotestosterone (DHT) in target cells. The AR has been localized in the uteri of the rat, human, rhesus monkey and dog (Kimura et al. 1993, Pelletier et al. 2000, Vermeirsch et al. 2002). These previous experiments demonstrated some differences among species in relative content of $\mathrm{AR}$ in myometrial, stromal and epithelial cells. In the porcine uterus, the AR has been detected using immunoblot analysis (Koziorowski et al. 1984), however description of the cellular distribution of the AR has been only preliminary (Vale-Cruz et al. 2001). To date, there is little information about factors that regulate AR expression in the uterus and other female reproductive organs.

The objectives of the present experiments were: (1) to examine the distribution and relative amounts of the AR in the uterus of gilts during estrus, diestrus and early pregnancy, and (2) to determine changes in amounts of $\mathrm{AR}$ and AR mRNA in the uterus of ovariectomized gilts following administration of sex steroids.

\section{Materials and Methods}

Post-pubertal gilts (cross of European breeds) were exposed to boars once daily to detect estrus. Gilts that exhibited at least one estrous cycle were allocated randomly to the experimental treatments described below. Steroids (Sigma Chemical Co., St Louis, MO, USA) were dissolved in corn oil, and administered (i.m.) to gilts according to experimental protocols that were approved by the University Agricultural Animal Care and Use Committee.

\section{Experiment 1}

The objectives of this experiment were to determine the distribution and relative amounts of immunoreactive AR in the pig uterus during estrus, diestrus and day 12 of pregnancy. Eight gilts were hysterectomized on day 0 (first day of estrus) or 12 of the estrous cycle ( $n=4$ per group). Four additional gilts were mated and hysterectomized on day 12 of pregnancy. Uterine horns of mated gilts were flushed with physiological saline to confirm pregnancy by observing elongating blastocysts. A small piece of uterus (about $1 \mathrm{~cm}^{2}$ of surface area), dissected across the uterine tissue layers, was obtained from the middle portion of a uterine horn and fixed in 4\% paraformaldehyde for $18 \mathrm{~h}$ at $4{ }^{\circ} \mathrm{C}$. Tissue samples were embedded in paraffin, cut into $8 \mu \mathrm{m}$ sections and mounted on glass slides (Superfrost plus). Sections were stored at $-20{ }^{\circ} \mathrm{C}$ until determination of AR by immunohistochemistry (IHC) as described below.

\section{Experiment 2}

The objectives of this experiment were to determine the effects of sex steroids on relative amounts of $A R$ and $A R$
mRNA in uterine tissue of ovariectomized gilts. Four to five weeks after ovariectomy, gilts received daily i.m. injections of one of the following treatments during four consecutive days: (1) progesterone $(2 \mathrm{mg} / \mathrm{kg}$ bodyweight $(\mathrm{BW})$ ), (2) estradiol-17 $\beta$ ( $\left.\mathrm{E}_{2}, 2 \mu \mathrm{g} / \mathrm{kg} \mathrm{BW}\right)$, (3) progesterone plus $E_{2}$ (same doses as 1 and 2 combined), (4) DHT $(7 \mu \mathrm{g} / \mathrm{kg} \mathrm{BW})$, and (5) corn oil (vehicle). Gilts were hysterectomized $24 \mathrm{~h}$ after receiving their last treatment. A small piece of uterus was excised, and then fixed, embedded in paraffin and sectioned as described in experiment 1 for determination of AR by IHC. An additional sample of endometrium (approximately $200 \mathrm{mg}$ ) was dissected from the middle portion of a uterine horn, frozen in liquid nitrogen and then stored at $-80{ }^{\circ} \mathrm{C}$. Total RNA was isolated from endometrial tissue using TRI Reagent (MRC, Inc., Cincinnati, OH, USA) and stored at $-80{ }^{\circ} \mathrm{C}$ for subsequent use in determination of AR mRNA by competitive reverse transcription-PCR (RT-PCR). Purity of RNA samples was verified by calculating the ratios of the absorbances at 260 and $280 \mathrm{~nm}$. The absorbance at $260 \mathrm{~nm}$ was used to calculate the concentrations of RNA. The integrity of RNA was determined by estimating the 28 s to 18 s rRNA ratios following agarose gel electrophoresis under denaturing conditions.

\section{Immunohistochemistry of $A R$}

The procedure used for determination of pig AR by IHC has been recently described (Cárdenas \& Pope 2002). The AR antibody, PA1-111A (Affinity Bioreagents, Inc., Golden, CO, USA) was produced against a 21-amino acid peptide that has 95\% sequence homology with the N-terminus of the porcine AR (GenBank accession AF202775). Briefly, tissue sections were deparaffinized, hydrated and subjected to antigen retrieval by incubating in $0.01 \mathrm{M}$ sodium citrate, $\mathrm{pH} 6.0$, for $30 \mathrm{~min}$ at $95^{\circ} \mathrm{C}$. Tissue sections were treated with $0 \cdot 3 \%$ hydrogen peroxide and then incubated in normal goat serum. Thereafter, sections were incubated with $\operatorname{AR}$ antibody $(8 \mu \mathrm{g} / \mathrm{ml})$ for $18 \mathrm{~h}$ at $4{ }^{\circ} \mathrm{C}$. This was followed by incubation in biotinylated goat anti-rabbit $\operatorname{IgG}$ and then in Vectastain $\mathrm{ABC}$ reagent (Vector Laboratories, Inc., Burlingame, CA, USA). Sections were incubated for $8 \mathrm{~min}$ with diaminobenzidine substrate solution containing nickel chloride to produce gray-black staining (Vector Laboratories). Adjacent tissue sections were processed as negative controls in which the primary antibody was pre-absorbed with neutralizing peptide, or the primary or secondary antibody was replaced with PBS. All sections for each experiment were processed simultaneously.

Sections were examined using a Zeiss Axioskop microscope. Digital images (8 bit, 256 tones of gray) of luminal epithelium, glandular epithelium (from the basal and adluminal regions of the endometrium) and myometrium were obtained at a magnification of $400 \times$ using a CCD camera attached to the microscope and Optimas software 
(Media Cybernetics, Inc., Silver Spring, MD, USA). These images were used for densitometric analysis of AR immunostaining by outlining stained nuclei using a minimum threshold value of gray and determining the gray values (in pixels) of outlined nuclei using the ImageJ program (National Institutes of Health Internet page: http://rsb.info.nih.gov/ij/). The relative amount of AR in a cell type of a particular sample was represented by the AR staining intensity, which was estimated as the average gray value of the stained nuclei corrected for the gray value of the background.

\section{Western blotting of $A R$}

Verification of AR binding by the AR antibody PA1$111 \mathrm{~A}$ was performed by Western blotting. Endometrial tissue obtained from gilts on day 0 or 12 of the estrous cycle was transferred to lysis buffer $(1 / 10$ (w/v), $50 \mathrm{mM}$ Tris- $\mathrm{HCl}, \mathrm{pH} 6 \cdot 8,2 \%$ sodium dodecyl sulfate (SDS, w/v), $10 \%$ glycerol (v/v), 5\% beta-mercaptoethanol (v/v)) and homogenized for $30 \mathrm{~s}$ in a PowerGen 700 homogenizer (Fisher Scientific, Pittsburgh, PA, USA) set at medium speed. Aliquots of the homogenate were incubated at $95{ }^{\circ} \mathrm{C}$ for $10 \mathrm{~min}$ and then centrifuged at $14000 \mathrm{~g}$ for $3 \mathrm{~min}$. The supernatant was recovered and stored at $-80{ }^{\circ} \mathrm{C}$. Protein concentration was determined using the Bradford Reagent (Sigma Chemical Co.) and BSA as standard. Sample aliquots equivalent to $100 \mu \mathrm{g}$ protein, and a mixture of pre-stained molecular weight standards were subjected to discontinuous SDS gel electrophoresis on 9\% polyacrylamide (Gallagher 1999) using a Mighty Small vertical slab gel unit (Hoefer Scientific Instruments, San Francisco, CA, USA). Proteins were blotted onto a PVDF membrane (Immobilon-P, Millipore Corporation, Bedford, MA, USA) at $4{ }^{\circ} \mathrm{C}$, overnight, using an electrophoretic transfer cell (Mini Trans-Blot, Bio-Rad Laboratories, Hercules, CA, USA) and transfer buffer (25 mM Tris base, $192 \mathrm{mM}$ glycine, 10\% methanol (v/v), $\mathrm{pH} 8 \cdot 3$ ). Detection of AR on the membrane was performed using the same kits described above for detection of AR by IHC. Membranes were incubated in TTBS $(100 \mathrm{mM}$ Tris.Cl,

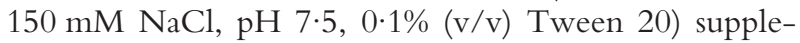
mented with normal goat serum $(1.5 \% \mathrm{v} / \mathrm{v})$ for $2 \mathrm{~h}$ to block non-specific binding sites, and then treated with AR antibody (PA1-111A, $8 \mu \mathrm{g} / \mathrm{ml}$ in TTBS) at $4{ }^{\circ} \mathrm{C}$ for $20 \mathrm{~h}$. Membranes were washed in TTBS and incubated in biotinylated goat anti-rabbit $\operatorname{IgG}(100 \mu \mathrm{l}$ in $50 \mathrm{ml}$ of TTBS) for $30 \mathrm{~min}$ at room temperature, washed again, and then incubated in a solution of avidin DH and biotinylated horseradish peroxidase (Vectastain ABC reagent, prepared in TTBS according to the manufacturer's instructions and further diluted to $1 / 5$, and the concentration of $\mathrm{NaCl}$ increased to $0.5 \mathrm{M}$ ) for $30 \mathrm{~min}$. For color development, the membranes were washed in TTBS and incubated in a solution containing the peroxidase substrate diaminobenzidine and nickel chloride. Membranes that served as controls were not treated with either AR antibody or goat anti-rabbit IgG. Membranes were washed in water, allowed to dry and scanned for documentation.

\section{Competitive RT-PCR of $A R$}

The competitive RT-PCR of AR was performed using the GeneAmp RNA PCR Perkin Elmer kit (Roche Molecular Systems, Inc., Branchburg, NJ, USA) and homologous primers (forward, 5' AGC CTC TGG ACC AGT CAT TC 3'; reverse, 5' CAC CAT CTT CTG CCA GAG AC 3'). The RNA standard ('competitor') was constructed by introducing a $40 \mathrm{bp}$ deletion in an $\mathrm{AR}$ product (242 bp) obtained using a previously described RT-PCR protocol (Cárdenas et al. 2002). The deletion was introduced by re-amplifying the AR product using the reverse primer given above and a modified forward primer (5' CAT ATT GAA GGC TAT GAG TGG CGT AGT GTG TGC C 3'). The resulting product was cloned into the pGEM-T Easy vector (Promega, Madison, WI, USA) and then sequenced to verify the deletion and establish its orientation in the vector. The vector was linearized using NcoI enzyme and then used to synthesize the RNA competitor by run-off in vitro transcription using SP6 RNA polymerase (Riboprobe In Vitro Transcription System, Promega). The RNA was extracted from the reaction solution after digestion of the DNA template using RQ1 DNase (Promega). Synthesis of the AR mRNA competitor was verified by agarose gel electrophoresis and its concentration was determined by measuring the absorbance at $260 \mathrm{~nm}$. The competitor was then divided into aliquots and stored at $-80{ }^{\circ} \mathrm{C}$.

For competitive RT-PCR, four reverse transcription reactions were prepared for each sample containing $250 \mathrm{ng}$ of total RNA and different amounts of RNA competitor. The amounts of competitor RNA that produced an appropriate pattern of competition with wild-type RNA (Freeman et al. 1999) were determined in preliminary assays by testing different ranges of competitor, and were set at $0 \cdot 25,1,4$ and $16 \mathrm{pg}$ (equivalent to $2 \cdot 6,10 \cdot 5,42 \cdot 2$ and 168.6 fmol respectively) per tube. First strand cDNA was synthesized using Maloney murine leukemia virus reverse transcriptase primed with random hexamers. Concentrations of the other components were those indicated by the kit manufacturer (see above). Tubes were incubated for $10 \mathrm{~min}$ at room temperature, $30 \mathrm{~min}$ at $42{ }^{\circ} \mathrm{C}$ and $5 \mathrm{~min}$ at $99^{\circ} \mathrm{C}$. PCR was performed using Taq DNA Polymerase, $1.5 \mathrm{mM} \mathrm{MgCl} 2$ and $0.3 \mu \mathrm{M}$ primers. Tubes were incubated for $1 \mathrm{~min}$ at $95{ }^{\circ} \mathrm{C}$ and then subjected to 25 cycles of $1 \mathrm{~min}$ at $95^{\circ} \mathrm{C}, 45 \mathrm{~s}$ at $55^{\circ} \mathrm{C}$ and $2 \mathrm{~min}$ at $72{ }^{\circ} \mathrm{C}$. Cycling was followed by $7 \mathrm{~min}$ of incubation at $72{ }^{\circ} \mathrm{C}$ and then cooling to $5{ }^{\circ} \mathrm{C}$. PCR products were separated by electrophoresis in 4.0\% NuSieve 3:1 agarose gel, visualized using ethidium bromide and UV illumination, and then photographed. Intensity of cDNA bands were obtained by image analysis (ImageJ program) and 


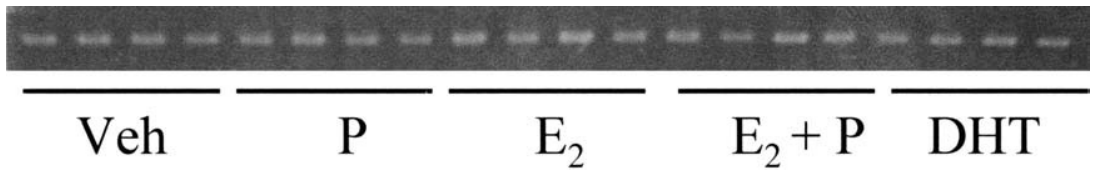

Figure 1 Ribosomal protein L-19 mRNA determined by RT-PCR in the endometrium of ovariectomized gilts (experiment 2) showing similar amounts of L-19 mRNA among samples. Veh, vehicle; $\mathrm{P}$, progesterone.
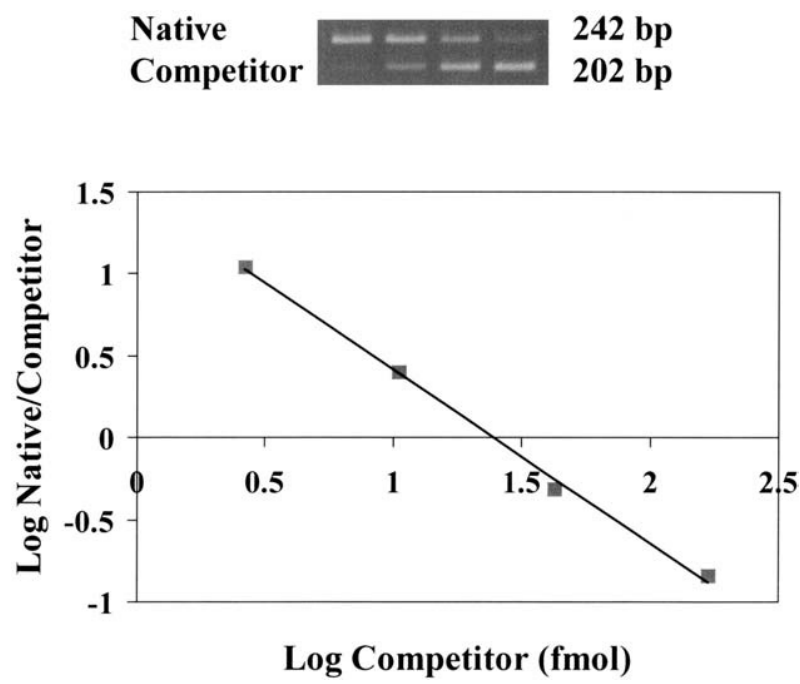

Figure 2 Determination of AR mRNA by competitive RT-PCR. Top, gel electrophoresis showing CDNA bands generated by native and increasing amounts of competitor AR mRNA in a representative sample. Bottom, regression analysis of the relationship between amounts of competitor ( $x$-axis) and native/competitor ratio of band intensity ( $y$-axis) performed to estimate the amounts of AR mRNA.

then plotted on logarithmic coordinates (amounts of competitor on the $x$-axis and native/competitor intensity ratio on the $y$-axis). The amount of AR mRNA in a sample was estimated as the amount of competitor equal to the amount of native RNA (native/competitor ratio of 1 equivalent to 0 in a $\log$ scale) determined using regression analysis. Slopes were not influenced by treatment $(P=0.36)$ and RT-PCR of ribosomal protein L19 (performed as described in Cárdenas \& Pope 2002) confirmed the absence of major differences in RNA degradation between samples (Fig. 1). Competitive RT-PCR data of AR determination in a representative sample is presented in Fig. 2. Intra- and inter-assay coefficients of variation of AR mRNA in a sample that was repeated three times in two assays were $<11 \cdot 0 \%$ and $13 \cdot 3 \%$ respectively.

\section{Statistical analysis}

The amounts of AR immunostaining in glandular epithelium at the basal and adluminal regions of the endometrium were compared using ANOVA for a split-plot design. AR immunostaining in the basal and adluminal regions were averaged to obtain an overall mean value of AR immunostaining in glandular epithelium for subsequently comparing with luminal epithelium and myometrium using a split-plot ANOVA. Means were compared by using the pdiff option of SAS (SAS Institute Inc., Cary, NC, USA). The amounts of AR mRNA in the whole endometrium were analyzed by using a one-way ANOVA and means compared by Fisher's protected LSD tests. $P \leq 0.05$ was considered significant.

\section{Results}

Experiment 1: distribution of the $A R$ in the pig uterus during the estrous cycle and early pregnancy

Immunostaining of the AR was detected in nuclei of various cell types of the pig uterus. AR immunostaining was relatively strong in luminal and glandular epithelia, and moderate in the myometrium. Endothelial cells and most nuclei of endometrial stroma exhibited moderate to weak, or no, AR immunostaining (Fig. 3). Some cells of the subepithelial stroma demonstrated relatively strong AR immunostaining. Immunostaining of AR in glandular epithelium was less $(P<0 \cdot 01)$ intense at the basal compared with the adluminal region of the endometrium, and was not influenced by reproductive stage or the interaction of reproductive stage by location (Table 1 and Fig. 3). The intensity of AR immunostaining was not different between glandular and luminal epithelia, but was less $(P<0 \cdot 05)$ in the myometrium compared with glandular and luminal epithelia (Table 2). Intensities of immunoreactive $\mathrm{AR}$ in glandular and luminal epithelia and myometrium were not influenced by reproductive stage $(P=0 \cdot 6)$, or by the interaction of stage by cell type $(P=0.33$, Table 2 and Fig. 3).

Results of Western blotting demonstrated that the AR antibody utilized for the IHC determinations specifically binds a protein of approximately $110 \mathrm{kDa}$ (Fig. 4). A protein of approximately $65 \mathrm{kDa}$ was stained weakly and nonspecifically. This nonspecific binding was not detected in the IHC procedure, suggesting that it may be intrinsic to membrane binding.

Experiment 2: amounts of $A R$ and $A R m R N A$ in the uterus of ovariectomized gilts treated with sex steroids

Uterine cell types that contained AR in ovariectomized gilts treated with sex steroids were the same as those 

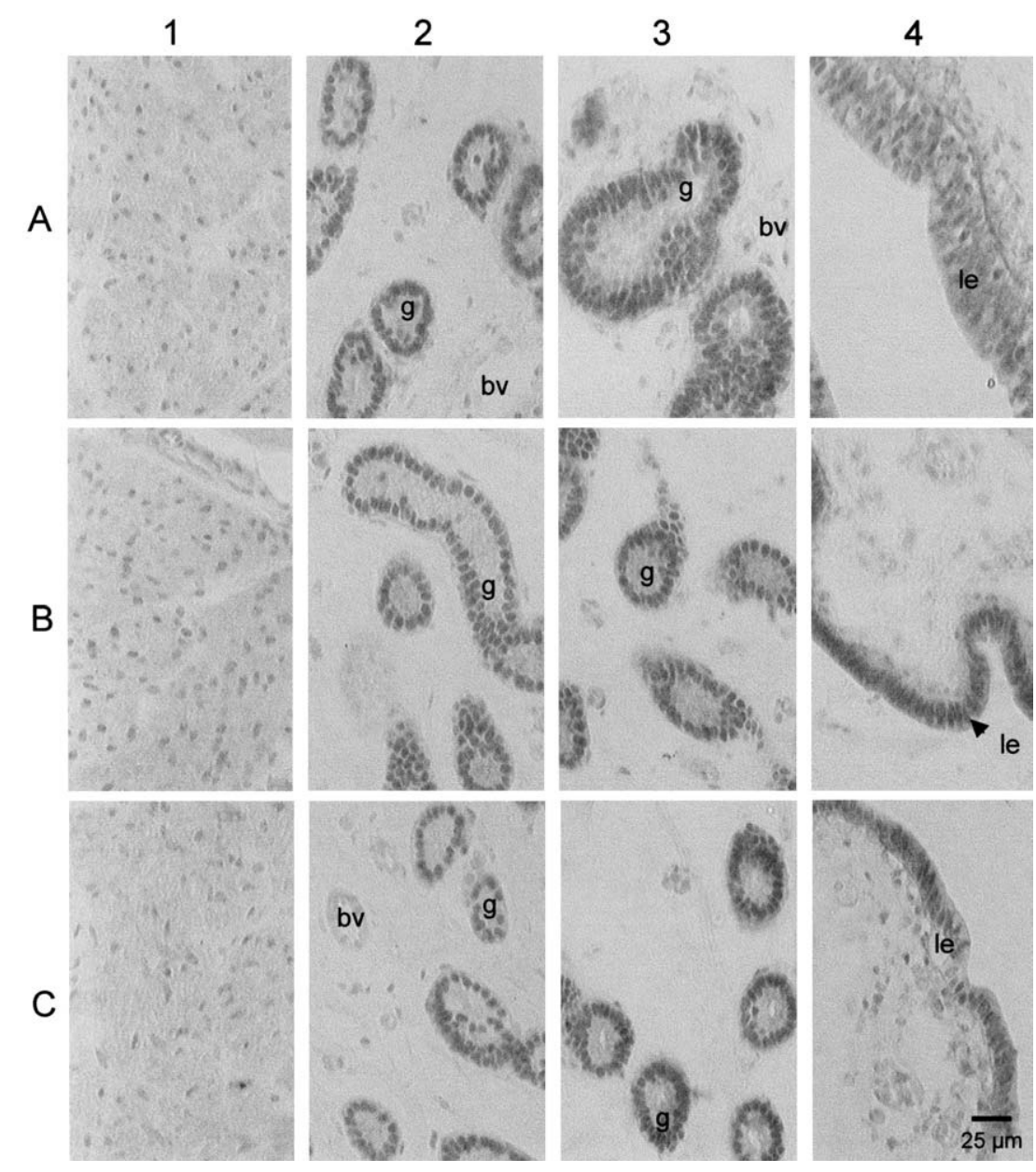

Figure $3 \mathrm{Immunohistochemical} \mathrm{detection} \mathrm{of} \mathrm{the} \mathrm{AR} \mathrm{in} \mathrm{the} \mathrm{uterus} \mathrm{of} \mathrm{gilts} \mathrm{at} \mathrm{estrus} \mathrm{(A),} \mathrm{day}$ 12 of the estrous cycle (B) and day 12 of pregnancy (C). 1, myometrium; 2, basal endometrium; 3, adluminal endometrium; 4, luminal epithelium. g, endometrial gland; le, luminal epithelium; bv, blood vessel.

Table 1 Intensity (mean gray value) of AR immunostaining in glandular epithelium at the basal (GEB) and the adluminal (GEL) regions of the endometrium in gilts during the estrous cycle and early pregnancy ${ }^{\mathrm{a}}$

\begin{tabular}{llll} 
& \multicolumn{1}{l}{ GEB } & & GEL \\
Stage $^{\text {b }}$ & & \\
Estrus (day 0) $^{\text {Luteal phase (day 12) }}$ & $66 \cdot 6 \pm 3 \cdot 8$ & & $75 \cdot 9 \pm 3 \cdot 8$ \\
Pregnancy (day 12) & $64 \cdot 5 \pm 3 \cdot 8$ & & $81 \cdot 4 \pm 3 \cdot 8$ \\
Mean & $69 \cdot 3 \pm 2 \cdot 2^{\mathrm{c}}$ & & $81 \cdot 8 \pm 3 \cdot 8$ \\
& & $79 \cdot 7 \pm 2 \cdot 2^{\mathrm{d}}$ \\
\hline
\end{tabular}

${ }^{a}$ Values are least-squares means \pm S.E., $n=4$ gilts per stage.

${ }^{b}$ No effect of physiological stage $(P=0 \cdot 32)$ or stage $\times$ location $(P=0 \cdot 28)$.

c,d Means differ $(P<0 \cdot 01)$.

described for intact gilts in experiment 1 (Fig. 5). Intensities for immunoreactive AR in the uterus of ovariectomized gilts was influenced by sex steroid treatment $(P=0.03)$ and cell type $(P=0 \cdot 001)$, but there was no
Table 2 Intensity (mean gray value) of AR immunostaining in the uterus of gilts during the estrous cycle and early pregnancy ${ }^{a}$

\begin{tabular}{|c|c|c|c|}
\hline & Myometrium & $\begin{array}{l}\text { Glandular } \\
\text { epithelium }\end{array}$ & $\begin{array}{l}\text { Luminal } \\
\text { epithelium }\end{array}$ \\
\hline \multicolumn{4}{|l|}{ Stage $^{b}$} \\
\hline Estrus (day 0 ) & $42 \cdot 9 \pm 3 \cdot 5$ & $71 \cdot 2 \pm 3 \cdot 5$ & $74 \cdot 5 \pm 4 \cdot 0$ \\
\hline Luteal phase (day 12) & $43 \cdot 8 \pm 3 \cdot 5$ & $79 \cdot 2 \pm 3 \cdot 5$ & $85 \cdot 6 \pm 3 \cdot 5$ \\
\hline Pregnancy (day 12) & $44 \cdot 4 \pm 3 \cdot 5$ & $73 \cdot 1 \pm 3 \cdot 5$ & $69 \cdot 7 \pm 4 \cdot 0$ \\
\hline Mean & $43 \cdot 7 \pm 2 \cdot 0^{c}$ & $74 \cdot 5 \pm 2 \cdot 0^{d}$ & $76 \cdot 6 \pm 2 \cdot 2^{d}$ \\
\hline
\end{tabular}

treatment by cell type interaction $(P=0 \cdot 67)$. AR immunostaining in glandular and luminal epithelia and in the myometrium was greater $(P<0 \cdot 05)$ in gilts treated with $\mathrm{E}_{2}$, 


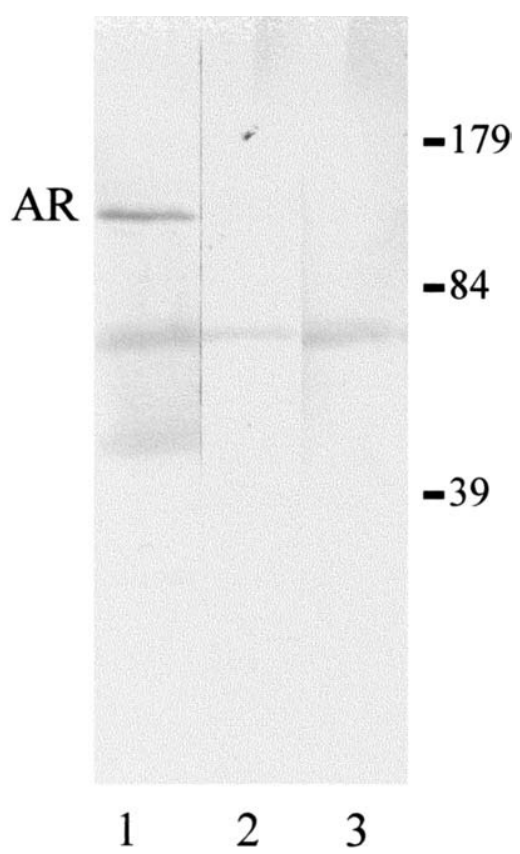

Figure 4 Verification of AR binding by Western blotting in pig endometrium. AR was detected as a band of approximately $110 \mathrm{kDa}$ (lane 1). The weak staining of a band of approximately $65 \mathrm{kDa}$ was non-specific. Lanes 2 and 3 are controls that were not treated with first or second antibody respectively. The apparent molecular weight of markers are given on the right in kDa.

progesterone, or $\mathrm{E}_{2}$ plus progesterone relative to gilts treated with DHT or vehicle (Table 3 and Fig. 5). AR immunostaining in glandular epithelium was not different $(P>0.05)$ between gilts treated with DHT or vehicle, or between gilts treated with $\mathrm{E}_{2}$, progesterone, or $\mathrm{E}_{2}$ plus progesterone (Table 3 and Fig. 5). Similar to experiment 1 , AR immunostaining was less $(P<0 \cdot 01)$ in the myometrium than in glandular or luminal epithelium (Table 3 and Fig. 5). Likewise, AR staining intensity in glandular epithelium was lesser $(P<0 \cdot 01)$ in the basal compared with the adluminal region of the endometrium $(91 \cdot 3 \pm 2 \cdot 9$ and $102.4 \pm 2.9$ respectively, see also Fig. $5 \mathrm{G}$ ).

Amounts of AR mRNA in whole endometrium of ovariectomized gilts treated with progesterone, DHT, $\mathrm{E}_{2}$ plus progesterone, or vehicle were not different $(P>0 \cdot 05$, Fig. 6), however gilts receiving these treatments had smaller $(P<0 \cdot 01)$ amounts of AR mRNA in the whole endometrium compared with gilts administered $E_{2}$ (Fig. 6).

\section{Discussion}

The AR was detected in nuclei of most cell types of the pig uterus including epithelial, stromal, myometrial and endothelial cells. The greatest cellular concentration of the
AR was detected in glandular and luminal epithelia, and was approximately $40 \%$ less abundant in the myometrium. Other cell types exhibited variable and, in most instances, relatively low AR content. The relative abundance of AR in endometrial epithelia suggests that androgens might influence function(s), yet to be determined, in these cells. As in pigs, AR and its mRNA were detected in glandular and luminal epithelia, stroma and myometrium of the adult rat uterus (Hirai et al. 1994, Pelletier et al. 2000). In contrast, the AR was not detected in the uteri of immature rats (Weihua et al. 2002), suggesting associations of AR gene expression with postnatal uterine development. The relative distribution of the AR among uterine cell types appears to be different in women, monkeys and dogs compared with pigs and adult rats. In primates and dogs, immunostaining of AR was greater in endometrial stroma and myometrium than in glandular epithelium (Mertens et al. 1996, Slayden et al. 2001, Vermeirsch et al. 2002). Differences in cellular distribution of AR among species are probably associated with different roles of AR in the uterus and might also involve unique regulatory mechanisms of AR gene expression.

Immunostaining of AR in glandular epithelium was greater at the adluminal compared with the basal region of the endometrium and did not change during different reproductive stages or in ovariectomized gilts treated with sex steroids. This pattern of AR present in glandular epithelium has not been reported in other species and its biological significance is unclear. Uterine glands develop from the luminal epithelium by invagination (reviewed by Gray et al. 2001) and regions of cell proliferation are located at the apical and middle portions of glands (Tarleton et al. 1999, Taylor et al. 2000). There are indications from experiments in mice that DHT reduces cell death in endometrial epithelia (Terada et al. 1990). If androgens decrease cell death in the pig endometrium (to be confirmed), then increased $A R$ expression in epithelium located at the upper part of uterine glands might help epithelial cell survival at a region where cell proliferation is reduced.

The amounts of AR in glandular and luminal epithelia or myometrium did not differ among gilts at estrus, diestrus or day 12 of pregnancy when the uterus is exposed to relatively high concentrations of $E_{2}$, progesterone, or progesterone and $E_{2}$ ( $E_{2}$ from elongating blastocysts) respectively. In support, no significant differences in amounts of immunoreactive AR were detected in endometrial epithelia or myometrium of ovariectomized gilts treated for 4 days with $\mathrm{E}_{2}$, progesterone, or $\mathrm{E}_{2}$ plus progesterone in experiment 2 . These observations indicate that in pigs, either estrogen or progesterone, or their combination, would induce AR in endometrial epithelia and myometrium. AR might be needed for some of the actions of $E_{2}$ and progesterone in the uterus. For instance, it has been proposed that induction of $\mathrm{AR}$ by $\mathrm{E}_{2}$ in the rat uterus might amplify the effects of $\mathrm{E}_{2}$ on epithelial cell 

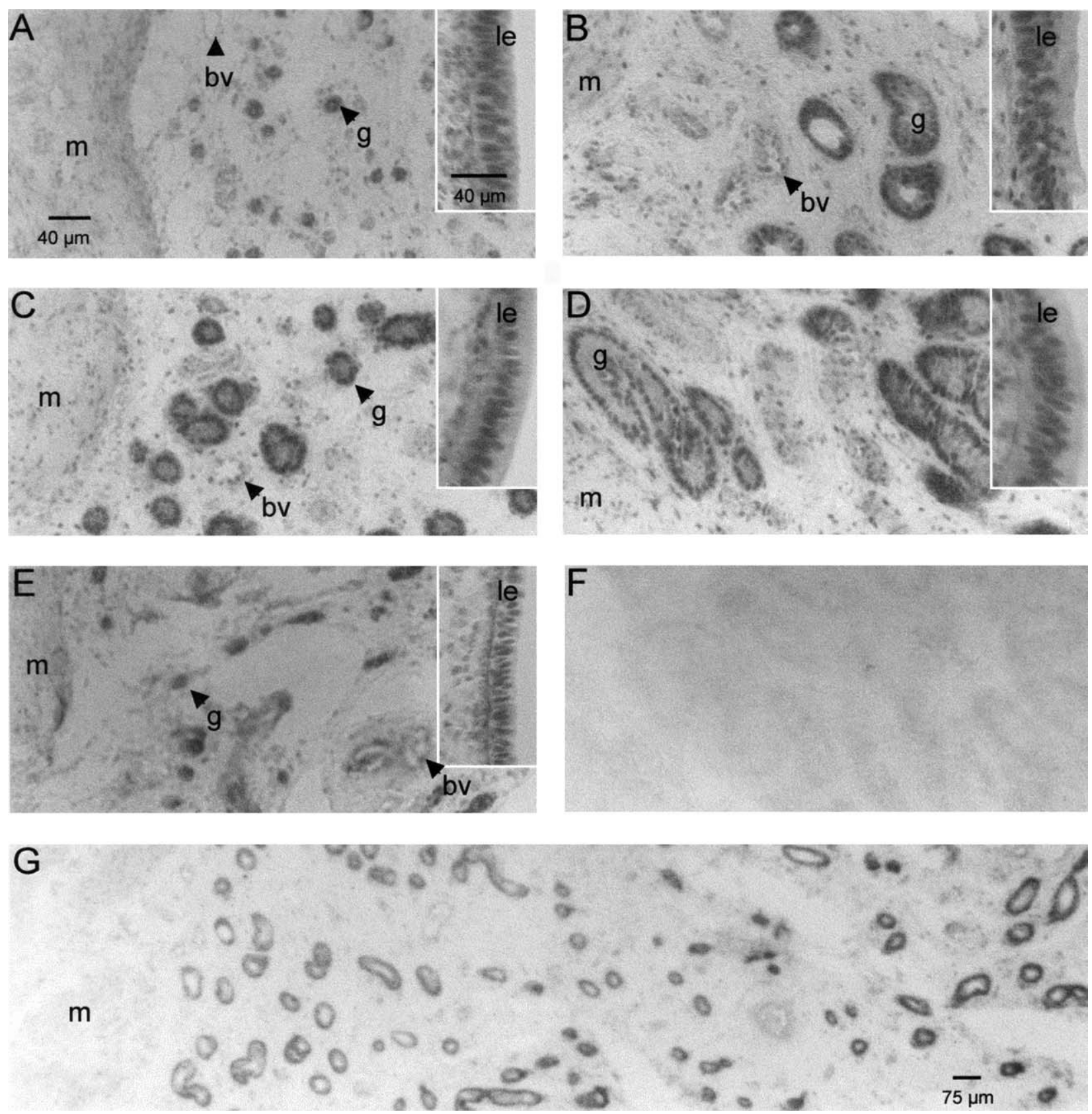

Figure 5 Immunohistochemical detection of the AR in the uterus of ovariectomized gilts treated with vehicle (corn oil, A), $E_{2}(B)$, progesterone (C), $E_{2}$ plus progesterone (D), or DHT (E). (F) Negative control (section adjacent to D in which AR antibody pre-incubated with immunizing peptide was used). (G) Section showing differential AR immunostaining across the endometrium of a gilt treated with $E_{2}$. Insets, luminal epithelium (le). m, myometrium; g, endometrial gland; bv, blood vessel; be, basal endometrium; ae, adluminal endometrium.

proliferation through induction of insulin-like growth factor by AR (Weihua et al. 2002).

Estradiol-17 $\beta$ and progesterone, or their combination, upregulated AR in glandular and luminal epithelia and myometrium of ovariectomized gilts. Treatment of gilts with $\mathrm{E}_{2}$ also produced an approximately twofold increase in AR mRNA in whole endometrium relative to gilts that received vehicle or other steroid treatments. Upregulation of AR by $E_{2}$ observed in the present experiments agrees with results in rhesus monkeys and immature rats treated with $\mathrm{E}_{2}$ (Slayden et al. 2001, Weihua et al. 2002). Progesterone did not affect the amounts of AR mRNA 
Table 3 Intensity (mean gray value) of AR immunostaining in luminal and glandular epithelia and myometrium of ovariectomized gilts treated with sex steroids ${ }^{\mathrm{a}}$

\begin{tabular}{|c|c|c|c|c|}
\hline & Myometrium & $\begin{array}{l}\text { Glandular } \\
\text { epithelium }\end{array}$ & $\begin{array}{l}\text { Luminal } \\
\text { epithelium }\end{array}$ & Mean \\
\hline \multicolumn{5}{|l|}{ Treatment } \\
\hline Vehicle & $48 \cdot 6 \pm 5 \cdot 7$ & $76 \cdot 8 \pm 5 \cdot 7$ & $90 \cdot 5 \pm 5 \cdot 7$ & $72 \cdot 0 \pm 5 \cdot 6^{\mathrm{d}}$ \\
\hline Progesterone & $72 \cdot 3 \pm 7 \cdot 5$ & $112 \cdot 9 \pm 7 \cdot 2$ & $100 \cdot 4 \pm 9 \cdot 7$ & $95 \cdot 2 \pm 8 \cdot 0^{c}$ \\
\hline $\mathrm{E}_{2}$ & $58 \cdot 8 \pm 5 \cdot 7$ & $104 \cdot 8 \pm 5 \cdot 7$ & $106 \cdot 4 \pm 5 \cdot 7$ & $90 \cdot 0 \pm 5 \cdot 6^{\mathrm{e}}$ \\
\hline Progesterone $+\mathrm{E}_{2}$ & $65 \cdot 5 \pm 5 \cdot 7$ & $109 \cdot 2 \pm 5 \cdot 7$ & $107 \cdot 5 \pm 5 \cdot 7$ & $94 \cdot 1 \pm 5 \cdot 6^{\mathrm{e}}$ \\
\hline DHT & $46 \cdot 3 \pm 5 \cdot 7$ & $83 \cdot 3 \pm 5 \cdot 7$ & $89 \cdot 5 \pm 5 \cdot 7$ & $73 \cdot 0 \pm 5 \cdot 6^{d}$ \\
\hline Mean & $58 \cdot 3 \pm 2 \cdot 7^{\mathrm{b}}$ & $97 \cdot 4 \pm 2 \cdot 7^{c}$ & $98 \cdot 9 \pm 3 \cdot 0^{c}$ & \\
\hline
\end{tabular}

${ }^{a}$ Values are least-squares means \pm S.E., $n=4$ gilts per treatment.

b,c Main effect of type of tissue. Means having different superscripts differ $(P<0 \cdot 01)$,

d,e Main effect of treatment. Means having different superscripts differ $(P<0 \cdot 05)$.

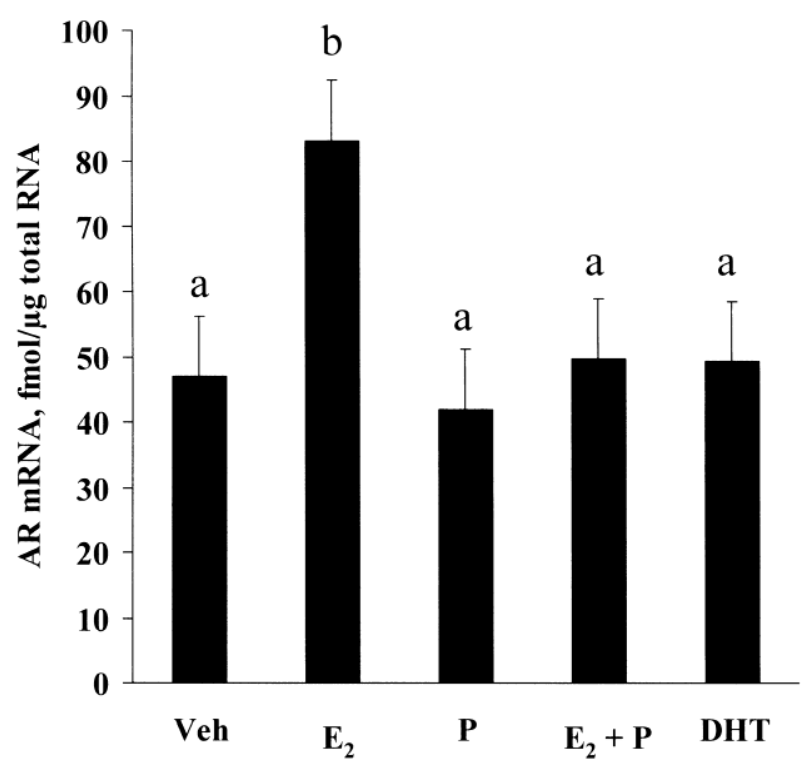

Figure 6 Mean concentrations of AR mRNA determined by quantitative RT-PCR in the endometrium of ovariectomized gilts ( $n=4$ per group) treated for 4 days with sex steroids or vehicle. Bars having different letters differ $(P<0 \cdot 01)$. Error bars represent S.E. Veh, vehicle; $\mathrm{P}$, progesterone.

and, instead, inhibited the effect of $\mathrm{E}_{2}$ on $\mathrm{AR}$ mRNA. The effects of progesterone on AR mRNA in whole endometrium were not parallel to the positive effects of progesterone on AR protein. Whether this was due to the presence of multiple cell types in samples utilized for RT-PCR, or post-transcriptional regulation, remains to be elucidated. In rhesus monkeys, treatment with $E_{2}$ and progesterone increased (larger dose of progesterone) or decreased (smaller dose of progesterone) AR protein and/or mRNA in endometrial stroma compared with $E_{2}$ alone (Adesanya-Famuyiwa et al. 1999, Slayden et al. 2001). Inhibitory effects of progesterone on AR mRNA were also observed in human endometrial stromal cells in vitro (Iwai et al. 1995). An inhibitory effect of progesterone on AR would be consistent with a decrease in uterine $\mathrm{AR}$ observed in primates during the secretory phase of the menstrual cycle (Mertens et al. 1996, Slayden et al. 2001). Together, these results indicate that progesterone decreases the amounts of AR mRNA, however the effects of progesterone on $\mathrm{AR}$ protein has varied between species or studies.

Unlike $E_{2}$ and progesterone, DHT $(7 \mu \mathrm{g} / \mathrm{kg} \mathrm{BW})$ did not alter the amounts of AR protein in glandular and luminal epithelia or myometrium. Likewise, DHT did not alter the amounts of AR mRNA in whole endometrium. In reproductive organs of male rats and cultured endometrial stromal cells, androgens decreased the amounts of AR mRNA (Shan et al. 1990, Quarmby et al. 1990, Iwai et al. 1995) or increased the amounts of AR protein (Takeda et al. 1991, Prins \& Birch 1993). It is important to note that the doses of androgens injected into male rats in the experiments cited above were greater $(\geq 400 \mu \mathrm{g} / \mathrm{kg})$ than the dose of DHT $(7 \mu \mathrm{g} / \mathrm{kg})$ used in the present study in female pigs. Females normally have lower plasma concentrations of androgens than males and the dose utilized was similar to a dose of testosterone previously shown to increase the plasma concentrations of this hormone from $0 \cdot 2$ to $1.2 \mathrm{ng} / \mathrm{ml}$ in gilts (Cárdenas \& Pope 1994). It is possible that greater amounts of androgens or longer duration of treatment with androgens might upregulate $\mathrm{AR}$ in the uterus. For instance, long-term androgen treatment to women increased immunoreactive $A R$ in myometrial and endometrial stroma (Chadha et al. 1994).

In conclusion, the AR was present in most cell types of the pig uterus but mainly in glandular and luminal epithelia. The amounts of AR were not significantly altered throughout the estrous cycle and early pregnancy. Estradiol-17 $\beta$ and progesterone exerted regulatory effects on $\mathrm{AR}$ gene expression in the porcine endometrium and myometrium. 


\section{Acknowledgements}

Salaries and research support provided by State and Federal funds appropriated to The Ohio Agric. Res. and Dev. Center and The Ohio State University. Manuscript No. 37-02AS

\section{References}

Adesanya-Famuyiwa OO, Zhou J, Wu G \& Bondy C 1999 Localization and sex steroid regulation of androgen receptor gene expression in rhesus monkey uterus. Obstetrics and Gynecology 93 265-270.

Armstrong DT, Moon YS \& Leung PC 1976 Uterotrophic effects of testosterone and 5 alpha-dihydrotestosterone in intact and ovariectomized immature female rats. Biology of Reproduction 15 107-114.

Cárdenas H \& Pope WF 1994 Administration of testosterone during the follicular phase increased the number of corpora lutea in gilts. Journal of Animal Science 72 2930-2935.

Cárdenas H \& Pope WF 2002 Androgen receptor and folliclestimulating hormone receptor in the pig ovary during the follicular phase of the estrous cycle. Molecular Reproduction and Development 62 92-98.

Cárdenas H, Herrick JR \& Pope WF 2002 Increased ovulation rate in gilts treated with dihydrotestosterone. Reproduction 123 527-533.

Chadha S, Pache TD, Huikeshoven JM, Brinkmann AO \& van der Kwast TH 1994 Androgen receptor expression in human ovarian and uterine tissue of long-term androgen-treated transsexual women. Human Pathology 25 1198-1204.

Fisher HE, Bazer FW \& Fields MJ 1985 Steroid metabolism by endometrial and conceptus tissues during early pregnancy and pseudopregnancy in gilts. Journal of Reproduction and Fertility $\mathbf{7 5}$ 69-78.

Freeman WM, Walker SJ \& Vrana KE 1999 Quantitative RT-PCR: pitfalls and potentials. BioTechniques 26 112-125.

Gallagher SR 1999 One-dimensional SDS gel electrophoresis of proteins. In Current Protocols in Molecular Biology, pp 10-2A.110·2A.34. Eds FM Ausubel, R Brent, RE Kingston, DD Moore, JG Seidman, JA Smith \& K Struhl. Chichester: John Wiley \& Sons, Inc.

Grant SA, Hunter MG \& Foxcroft GR 1989 Morphological and biochemical characteristics during ovarian follicular development in the pig. Journal of Reproduction and Fertility 86 171-183.

Gray CA, Bartol FF, Tarleton BJ, Wiley AA, Johnson GA, Bazer FW \& Spencer TE 2001 Developmental biology of uterine glands. Biology of Reproduction 65 1311-1323.

Hirai M, Hirata S, Osada T, Hagihara K \& Kato J 1994 Androgen receptor mRNA in the rat ovary and uterus. Journal of Steroid Biochemistry and Molecular Biology 49 1-7.

Iwai M, Kanzaki H, Fujimoto M, Kojima K, Hatayama H, Inoue T, Higuchi T, Nakayama H, Mori T \& Fujita J 1995 Regulation of sex steroid receptor gene expression by progesterone and testosterone in cultured human endometrial stromal cells. Journal of Clinical Endocrinology and Metabolism 80 450-454.

Kimura N, Mizokami A, Oonuma T, Sasano H \& Nagura H 1993 Immunohistochemical localization of androgen receptor with polyclonal antibody in paraffin-embedded human tissue. Journal of Histochemistry and Cytochemistry 41 671-678.

Koziorowski M, Kotwica G, Stefanczyk S \& Krzymowski T 1984 Estradiol, progesterone and testosterone receptors for pig endometrium and myometrium at various stages of the estrous cycle. Experimental and Clinical Endocrinology 84 285-293.

Legrand C, Marie J \& Maltier JP 1984 Testosterone, dihydrotestosterone, androstenedione and dehydroepiandrosterone concentrations in placentae, ovaries and plasma of the rat in late pregnancy. Acta Endocrinologica 105 119-125.

Mertens HJMM, Heineman MJ, Koudstaal J, Theunissen P \& Evers JLH 1996 Androgen receptor content in human endometrium. European Journal of Obstetrics, Gynecology and Reproductive Biology 70 11-13.

Pelletier G, Labrie C \& Labrie F 2000 Localization of estrogen receptor alpha, estrogen receptor beta and androgen receptors in the rat reproductive organs. Journal of Endocrinology 165 359-370.

Prins GS \& Birch L 1993 Immunocytochemical analysis of androgen receptor along the ducts of the separate rat prostate lobes after androgen withdrawal and replacement. Endocrinology 132 169-178.

Przala J, Wiezak T, Grazul A \& Cieplinska E 1984 The effect of prolactin on estradiol-17 beta and testosterone plus 5 alphadihydrotestosterone secretion by porcine luteal cells in vitro. Experimental and Clinical Endocrinology 83 343-348.

Quarmby VE, Yarbrough WG, Lubahn DB, French FS \& Wilson EM 1990 Autologous downregulation of androgen receptor messenger ribonucleic acid. Molecular Endocrinology 4 22-28.

Sahlin L, Wang H, Masironi B, Holmgren A \& Erikson H 1999 Regulation of thioredoxin mRNA in the rat uterus by gonadal steroids. Journal of Steroid Biochemistry and Molecular Biology 68 203-209.

Shan LX, Rodriguez MC \& Janne OA 1990 Regulation of androgen receptor protein and mRNA concentrations by androgens in rat ventral prostate and seminal vesicles and in human hepatoma cells. Molecular Endocrinology 4 1636-1646.

Slayden OD, Nayak NR, Burton KA, Chwalisz K, Cameron ST, Critchley HO, Baird DT \& Brenner RM 2001 Progesterone antagonists increase androgen receptor expression in the rhesus macaque and human endometrium. Journal of Clinical Endocrinology and Metabolism 86 2668-2679.

Smith GD, Menino AR Jr, Rowe KE \& Stormshak F 1992 Steroids and plasminogen activator concentrations in follicular fluid of gilts at first and third estrus. Journal of Animal Science 70 3838-3843.

Takeda H, Nakamoto T, Kokontis J, Chodak GW \& Chang C 1991 Autoregulation of androgen receptor expression in rodent prostate: immunohistochemical and in situ hybridization studies. Biochemical and Biophysical Research Communications 177 488-496.

Tarleton BJ, Wiley AA \& Bartol FF 1999 Endometrial development and adenogenesis in the neonatal pig: effects of estradiol valerate and the antiestrogen ICI 182,780. Biology of Reproduction 61 253-263.

Taylor KM, Gray CA, Joyce MM, Stewart MD, Bazer FW \& Spencer TE 2000 Neonatal ovine uterine development involves alterations in expression of receptors for estrogen, progesterone, and prolactin. Biology of Reproduction 63 1192-1204.

Terada N, Yamamoto R, Takada T, Taniguchi H, Terakawa N, Li W, Kitamura Y \& Matsumoto K 1990 Inhibitory effect of androgen on cell death of mouse uterine epithelium. Journal of Steroid Biochemistry 36 305-310.

Vale-Cruz DS, Kowalski AA, Simmen FA \& Simmen RCM 2001 Expression of the androgen receptors in the peri-attachment porcine uterus. Biology of Reproduction 64 (Suppl 1) Abstract 452.

Vendola K, Zhou J, Adesanya OO, Weil SJ \& Bondy CA 1998 Androgens stimulate early stages of follicular growth in primate ovary. Journal of Clinical Investigations 101 2622-2629.

Vermeirsch H, Van den Broeck W, Coryn M \& Simoens P 2002 Immunohistochemical detection of androgen receptors in the canine uterus throughout the estrous cycle. Theriogenology 57 2203-2216.

Weihua Z, Ekman J, Almkvist Å, Saji S, Wang L, Warner M \& Gustafsson J-A 2002 Involvement of androgen receptor in $17 \beta$-estradiol-induced cell proliferation in rat uterus. Biology of Reproduction 67 616-623.

Received 7 February 2003

Accepted 28 February 2003 